\title{
Jean-Jacques Gonzales, Albert Camus, L'exil Absolu
}

\section{Emanuele Kanceff}

\section{Q OpenEdition}

\section{Journals}

\section{Edizione digitale}

URL: http://journals.openedition.org/studifrancesi/9673

DOI: $10.4000 /$ studifrancesi.9673

ISSN: 2421-5856

\section{Editore}

Rosenberg \& Sellier

\section{Edizione cartacea}

Data di pubblicazione: 1 décembre 2007

Paginazione: 697

ISSN: 0039-2944

\section{Notizia bibliografica digitale}

Emanuele Kanceff, «Jean-Jacques Gonzales, Albert Camus, L'exil Absolu», Studi Francesi [Online], 153

(LI | III) | 2007, online dal 30 novembre 2015, consultato il 09 janvier 2021. URL: http://

journals.openedition.org/studifrancesi/9673 ; DOI: https://doi.org/10.4000/studifrancesi.9673

\section{Questo documento è stato generato automaticamente il 9 janvier 2021.}

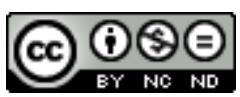

Studi Francesi è distribuita con Licenza Creative Commons Attribuzione - Non commerciale - Non opere derivate 4.0 Internazionale. 


\title{
Jean-Jacques Gonzales, Albert Camus, L'exil Absolu
}

\author{
Emanuele Kanceff
}

\section{NOTIZIA}

JeAn-JACques gonzales, Albert Camus, L'exil Absolu, Houilles, Éditions Manucius, 2007, Pp.

195 (Coll. «Le Marteau Sans Maître»).

1 Questo libro raccoglie le meditazioni su Camus di un autore non nuovo a temi algerini, che si sono espressi nei suoi scritti a partire dal racconto Oran (1998), attraverso 2000 ans d'Algérie (Séguier, 1998-2000), La guerre d'Algérie (Laffont, 2004), C'était leur France (Gallimard, 2007). Lo scopo del libro è appunto quello di spiegare la concezione dell'arte letteraria di Camus come una anabasi, un ritorno alle origini, di dimostrare come questa algerinità del grande romanziere abbia determinato una passione politica, una concezione filosofica, delle prese di posizione estetiche e letterarie che non furono passeggere e resistono, dopo tanti anni, alla corrosione dei tempi moderni. Questa utopia mediterranea che ha guidato il premio Nobel nella sua parabola letteraria approda all'autobiografia di un'assenza con il romanzo incompiuto Le Premier Homme e non è riducibile alla posizione degli europei d'Algeria che oltrepassa decisamente, in quanto si pone come un paradossale esilio nel proprio io, esilio assoluto, esatto contrario della filiazione, della passione identitaria e nazionale: antitesi, dunque, delle passioni nazionali che hanno sconvolto il xx secolo e costruito l'irreparabile della storia. Alla passione assassina della filiazione Camus ha opposto la passione dell'anonimato, della rinuncia al possesso, dell'incompiuto essenziale. La sua scrittura è la traccia di questo incompiuto, della sua nostalgia, di questa sua posizione di esilio assoluto. 